\title{
Epilepsia Partialis Continua as a Symptom of Alcohol Withdrawal in a Type 2 Diabetic Patient.
}

\author{
Chandan Kumar', Pal Satyajit Singh Athwal ${ }^{2}$, Akanksha Gulati ${ }^{3}$, Yaqoob Khan ${ }^{4}$, Yuvraj Singh ${ }^{5}$ \\ ${ }^{1}$ Assistant Professor, Department of Internal Medicine, Saraswathi Institute of Medical Sciences, U.P, India, ${ }^{2}$ M.B.B.S, Saraswathi Institute of Medical Sciences, \\ U.P, India, ${ }^{3}$ M.B.B.S, Indra Gandhi Medical College, H.P, India, ${ }^{4}$ M.B.B.S, Khyber Medical College, Peshawar, Pakistan, ${ }^{5} 3$ rd Year Medical Student, Ross University \\ School of Medicine, Miramar, FL, USA.
}

\section{Abstract}

Epilepsia partialis continua is a rare form of focal epilepsy or focal status epilepticus which mostly involves motor component. It leads to arrhythmic muscle jerks for a prolonged period of time. It can present as a single episode or multiple repetitive episodes. There are multiple etiological factors including vascular lesions and tumors. Presenting as alcohol withdrawal in a type 2 Diabetic patient makes it a rare phenomenon. We report a case of 55-year-old male with Epilepsia partialis continua after alcohol abstinence. Familiarity and diagnosis of this rare event is important because the treatment depends on the underlying etiology.

Keywords: Epilepsy, Alcohol, Diabetes Mellitus.

Corresponding Author: Dr. Akanksha Gulati, M.B.B.S, Indra Gandhi Medical College, H.P, India.

Received: April 2019

Accepted: May 2019

\section{Introduction}

Epilepsia partialis continua was first described in 1894 by Dr. Kozhevnikov a Russian neurologist. ${ }^{[1]}$ It is a rare type of focal seizures, which is mostly motor but can be sensorimotor in some cases. It can involve one group of muscle, entire limb or hemi body leading to continuous muscle arrhythmic contractions. ${ }^{[2]}$ Etiological factors include strokes, Rasmussen encephalitis, Nonketotic hyperglycaemia, cortical dysplasia and mitochondrial diseases. ${ }^{[3]}$ Alcohol can also induce a seizure or potentiate it by underlying metabolic or structural brain dysfunction by lowering the seizure threshold. ${ }^{[4]}$ Pathophysiology of Epilepsia partialis continua is still unknown and different mechanisms have been explained in the past. ${ }^{[5]}$ It is believed that the cortical focus involved in Epilepsia partialis continua is very active with high blood flow within the focus. ${ }^{[6]}$ Excessive NMDA can be the contributory factors, inflammatory mediators like interleukin $1 \mathrm{~B}$ and tumor necrosis factor-a can also be related to this rare variant. ${ }^{[7-9]}$ According to some case reports Non ketotic hyperglycaemia can presents as Epilepsia partialis continua. ${ }^{[10]}$ Management involves anti epileptics along with treating the underlying cause. Prognosis depends on the etiology, adults usually have good prognosis because of reversible etiological factors but the prognosis worsen in children with conditions like Rasmussen encephalitis.

\section{Case Report}

55-year-old male presented with altered sensorium and repeated twitching of face, which was continuous and getting worse. The twitching of facial muscle involved only right side of face. It started few hours ago and was continuous with 5-10 sec free interval. There was no history of any head trauma, diarrhea, fever or any previous epilepsy. Patient had a history of long-standing uncontrolled Type 2 Diabetes and chronic alcoholism. Lab work up is shown in table 1.0. Patient was chronic alcoholic with approximately $80 \mathrm{mg} /$ day, bilateral parotid enlargement and AST/ALT ratio indicates the same. Last drink was 5 days back. ECG showed normal sinus rhythm. Serum potassium and calcium were normal. Non contrast CT head was normal but EEG indicated partial seizure, loss of consciousness made it complex partial seizure. It was continuous with interval less than 10 seconds giving the diagnosis of Epilepsia partialis continua with the non ketotic hyperglycaemia and history of chronic alcoholism. We excluded all the other etiological factors. Blood for Beta hydroxybutyrate (BHB) was negative.

Table 1: Lab values

\begin{tabular}{|l|l|}
\hline Hemoglobin & $\mathbf{1 6} \mathbf{~ g m} / \mathbf{d l}$ \\
\hline Total Leukocytes count & 15000 \\
\hline Platelets- & $2.1 \mathrm{Lac}$ \\
\hline Random Blood sugar & $480 \mathrm{gm} / \mathrm{dl}$ \\
\hline Sodium & $135 \mathrm{Meq} / \mathrm{L}$ \\
\hline BUN & 35 \\
\hline AST/ALT & $>2 / 1$ \\
\hline Calculated Osmolarity & $309 \mathrm{mosm} / \mathrm{kg}$ \\
\hline
\end{tabular}

Patient was started on Diazepam; it was given four times at an interval of $10 \mathrm{~min}$ which resulted in resolution of seizure. Thiamine was given to the patient along with insulin and electrolyte monitoring. He regained consciousness after 24 
hours and Epilepsia partialis continua resolved completely.

\section{Discussion \& Conclusion}

Epilepsia partialis continua is a rare variant or status epilepticus of partial seizures. It is more common in males as compared to females as seen in our case patient is 55year-old male. ${ }^{[11]}$ Most of the clinician believe that partial seizure should last at least $60 \mathrm{~min}$ and free interval not exceeding more than $10 \mathrm{sec}$ to fulfil the criteria of EPC, in our case patient presented after a couple of hours of continuous complex partial seizure. According to Mameniškienè et al in a survey of 65 patient with Epilepsia partialis continua only 15 presented with complex partial seizure as in our case. The history of alcoholism and lack of any substantial history of epilepsy along with non ketotic hyperglycemia lead our team to think about this rare variant. ${ }^{[12]}$ There were no changes on $\mathrm{CT}$, no progressive motor deterioration and age helped us excluding the Rasmussen's encephalitis. There is no prevalence of Russian tick-borne spring-summer encephalitis in our area, which can also presents as Epilepsia Partialis Continua Patient last drink was 5 day ago which made us think about the alcohol withdrawal seizures. ${ }^{[3]}$ Alcohol withdrawal usually presents as Generalized tonic clonic but in our case it was Epilepsia Partialis Continua ${ }^{[4]}$ EEG showed partial seizures. We used Diazepam to abort the seizures but phenytoin or newer anti epileptics can also be used. Valproate or carbamazepine are inferior to phenytoin or phenobarbital. levetiracetam, lacosamide, and zonisamide can also be used for the management. ${ }^{[13]}$

\section{References}

1. Kozhevnikov, A.Y. A special type of cortical epilepsy. ([in Russian])Med Obozr. 1894; 42: 97-118.

2. Trinka, E., Cock, H., Hesdorffer, D., Rossetti, A.O., Scheffer, I.E., Shinnar, S. et al. A definition and classification of status epilepticus - report of the ILAE Task Force on Classification of Status Epilepticus. Epilepsia. 2015; 56: 1515-1523

3. Mameniškiené, Rūta et al. Epilepsia partialis continua: A review Seizure - European Journal of Epilepsy, Volume 44 , 74 - 80

4. Leone M, Bottacchi E, Beghi E, Morgando E, Mutani R, Amedeo G, et al. Alcohol use is a risk factor for a first generalized tonic-clonic seizure. Neurology. 1997;48(3):614-20.]

5. Vein AA, van Emde Boas W. Kozhevnikov epilepsy: the disease and its eponym. Epilepsia. $2011 \mathrm{Feb}$;52(2):212-8

6. Wendling F, Chauvel P, Biraben A, Bartolomei F. From intracerebral EEG signals to brain connectivity: identification of epileptogenic networks in partial epilepsy. Front Syst Neurosci. 2010;4:154

7. Mazarati AM, Wasterlain CG. Blockers of NMDA receptor restore paired-pulse inhibition in the rat dentate gyrus lesioned by perforant path stimulation. Neurosci. Lett. 1997 Oct 03;234(2-3):135-8.

8. Nabbout R, Vezzani A, Dulac O, Chiron C. Acute encephalopathy with inflammation-mediated status epilepticus. Lancet Neurol. 2011 Jan;10(1):99-108.

9. Specchio N, Fusco L, Claps D, Vigevano F. Epileptic encephalopathy in children possibly related to immune-mediated pathogenesis. Brain Dev. 2010 Jan;32(1):51-6.

10. Cokar O, Atakoy MD, Blok K. Non-ketotic hyperglycaemia presenting as epilepsia partialis continua. Seizure. 2004;13(4):264-69

11. Cockerell OC, Rothwell J, Thompson PD, Marsden CD, Shorvon SD. Clinical and physiological features of epilepsia partialis continua. Cases ascertained in the UK. Brain. 1996 Apr;119 ( Pt 2):393-407.)

12. Mameniškienè, R., Bast, T., Bentes, C., Canevini, M.P., Dimova, P., Granata, T. et al. Clinical course and variability of non-Rasmussen, non-stroke motor and sensory epilepsia partialis continua.

13. Johannessen SI, Tomson T. Pharmacokinetic variability of newer antiepileptic drugs: when is monitoring needed? Clin Pharmacokinet. 2006;45(11):1061-75

Copyright: (C) the author(s), 2019. It is an open-access article distributed under the terms of the Creative Commons Attribution License (CC BY 4.0), which permits authors to retain ownership of the copyright for their content, and allow anyone to download, reuse, reprint, modify, distribute and/or copy the content as long as the original authors and source are cited.

How to cite this article: Kumar C, Athwal PSS, Gulati A, Khan Y, Singh Y. Epilepsia Partialis Continua as a Symptom of Alcohol Withdrawal in a Type 2 Diabetic Patient. Asian J. Med. Res. 2019;8(2):ME09-ME10.

DOI: dx.doi.org/10.21276/ajmr.2019.8.2.ME4

Source of Support: Nil, Conflict of Interest: None declared. 